\title{
Association Between Flaming Efficiency and Liquefied Petroleum Gas Pressure and Flaming Time in Hazelnut Sucker Control Done Using a Flame Torch
}

\author{
Ali Tekgüler ${ }^{1, a, *}$

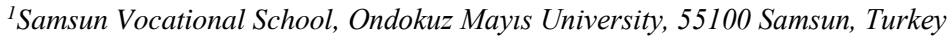 \\ *Corresponding author \\ A R T I C L E I N F O A B S T R A C T \\ Research Article \\ Turkish hazelnut (Corylus avellana L.) is naturally grown as a multi-stemmed shrub. This hazelnut \\ produces lots of suckers. Suckers compete with the main branches for nutrients and water. Because \\ the emergence of suckers negatively affects crop management in the hazelnut orchards are required \\ to eliminate at least twice a year. Flaming is an alternative method to chemical and mechanical \\ control methods. In this study, the effect of gas pressure, flaming time on fuel consumption and \\ flaming efficiency in hazelnut sucker control were evaluated. The trials were carried out in an shrub \\ ocak (in Turkish) type hazelnut orchard The results show that the torch flaming method is a useable \\ method for hazelnut basal sucker cleaning. Gas pressure and flaming time had significant effects \\ on fuel consumption and flaming efficiency. $150 \mathrm{~s}$ flaming duration and 3 bar pressure is sufficient \\ Received : 02/11/202 \\ Accepted : 05/11/2021 \\ for the flaming application. Durations above this time will increase fuel consumption and time loss.
}

\begin{tabular}{l|l} 
Keywords: & for the flaming application. Durations above this time will increase fuel consumption and time loss. \\
Efficiency & \\
Flaming & \\
Flaming time & \\
Gas pressure &
\end{tabular}

\section{Introduction}

Turkish hazelnut (Corylus avellana L.) cultivars, one of the major nut crops in the world are naturally grown as a multi-stemmed tree, due to the prolific production of basal shoots, or suckers (Y1ldız and Tekgüler, 2014) and have the most suckering aptitude among hazelnut varieties (Smith and Erdoğan, 2001; Tomasone et al., 2010; Y1ldız, 2016). Because the emergence of a large number of suckers negatively affects crop management in the hazelnut orchards (Tomasone et al., 2010), are required to eliminate at least twice a year with associated recurrent costs (Kılıç et al. 2009; Tomasone et al., 2010; Y1lmaz, 2017) to facilitate machine or manual harvest. Hazelnuts are mainly grown in the ocak system in Turkey. This system is a multistemmed planting system unique to Turkey (İslam, 2018). An ocak consists of usually six or eight plants planted around a circle 1-1.2 $\mathrm{m}$ in diameter (Beyhan, 2007).

Most suckering that come from newly formed bud primordia produced in healthy roots respond very well to cutting back to the ground level depending on the efficiency of manual, mechanical, chemical or thermal treatments (Dolci et al., 2005; Tomasone et al., 2009, 2010; Serdar and Akyüz, 2018).
In manual methods, suckers are removed with hand tools such as pruning shears or hoes. Indeed, to gain better yield, the manual desuckering that is a practice followed by the hazel producer has not been found effective due to high labourpower and costs and low-work efficiencies (Tous et al., 1994; Beyhan and Pınar, 1996; Serdar and Akyüz, 2018). Although mechanical method can be less costly and time consuming than manual removal, care is required to avoid truck damage with machinery (Serdar and Akyüz, 2018).

Herbicides are cheap and easy to use. However, pollution of groundwater and surface water, problems with herbicides, including pesticide residues in food, caused public awareness and limitation of herbicide use (Rifai et al., 2000; Brunclik and Lacko-Bartosova, 2001).

Flaming is the most widespread thermal weed control method in agriculture (Ascard, 1995). Flame weeding is often used for weed control in organic production where use of herbicides is prohibited (Sivesind et al., 2009).

Flaming exposes plant to heat stress, which causes the denaturation of membrane proteins resulting in a loss of cell function and dehydration and leading to their death or a reduction in their competitive ability (Ascard, 1997; 
Ulloa et al., 2010; Knezevic, 2017; Chehade et al., 2018; Horesh et al., 2019). Thermal sucker control is mostly done using a flame torch or steam (Tomasone et al., 2009). Flame weeding is less costly than hand-weeding (Nemming, 1993).

Tomasone et al. (2010) reported that the effectiveness of flaming, a thermal control method is in general good without damage to plants and flaming is easy to use, requires low-cost equipment and low-fuel consumption. Also, they noted that the hand-operated equipment could be too slow and too demanding for labour (machine operator and field workers).

It is generally accepted that a long time torch with high LPG pressure (GP) may increase flaming efficiency in sucker control, whereas it may have a negative effect on the health of hazelnut trees (Tomasone et al., 2010). Decreasing the GP and the duration of flaming time (FT) in hazelnut sucker control may reduce fuel consumption; however, flaming efficiency should be considered. The challenge in reducing GP and FT in the hazelnut sucker control by flaming is the uncertainty about how much fuel consumption can be declined without compromising the flaming efficiency. It is also unknown whether the GP and FT based on fuel consumption and flaming efficiency correlate with the increase in the GP and FT applied. Accordingly, the objectives of this study were to determine reduction possibility of fuel consumption without affecting flaming efficiency and association between flaming efficiency and GP and FT in hazelnut sucker control done using a flame torch.

\section{Material and Method}

The research was completed in a ocak-type hazelnut orchard in private ownership in Terme county in Samsun province. Some characteristics of the orchard are presented in Table 1. There is usually "Palaz" variety in the hazelnut garden. Average annual temperature and precipitation in the region are $14.3^{\circ} \mathrm{C}$ and $650.3 \mathrm{~mm}$, respectively.

The hazelnut orchard was divided into plots in accordance with the randomized plots with $3 \mathrm{GP} \times 6 \mathrm{FT}$ factorial design. To ensure that all hazelnut suckers were in the same development stage, suckers in the ocaks in all plots were mechanically cleaned with a pruning shears before the trial. Thus, the trial began when hazelnut suckers reached nearly $20 \mathrm{~cm}$ length; in other words, with younger bush form (Figure 1). The torch head makes an angle of $45^{\circ}$ with the horizontal. The torch was aimed directly at the growth point of the suckers and the suckers were burned from a height of about 5-6 cm in order to reduce possible heat losses. Since the flaming process is done at close range, no shield was used.

The flaming procedure was completed using a $2 \mathrm{~kg}$ LPG tank with 4 bar pressure. With this aim, a pressure meter and a torch head with $2 \mathrm{~m}$ pipe was mounted on the tank (Figure 2). When the amount of LPG within the tank reduced, the pressure fell, so GP treatment was set to high (H 4-3), moderate (M 3-2) and low (L 2-1) bar. Areas containing 54 ocaks were allocated for each GP treatment. The flaming procedure was applied 3 times to the same ocaks until the harvest.

For each ocak, the flaming area was calculated based on the projection of the outer stems in the ocaks (nearly 1.5 $\mathrm{m}^{2}$ ). One of the important factors determining the effect of the flame is the FT. In order to better see this effect each GP in areas allotted, FT of 30, 60, 90, 120, 150 and $180 \mathrm{~s}$ were applied. In these durations, all suckers were flamed within the determined area. Additionally, to guarantee suckers that were present or may later emerge were fully destroyed, each treatment was repeated three times until the harvest (21 June, 12 July and 5 August).

The calibration of the fuel consumption was done in the laboratory under controlled conditions. The amount of LPG (kg min-1) consumed at different pressures at certain times was measured by the decrease in the weight of the LPG tank. For this purpose, scale, with $1 \mathrm{~g}$ sensitivity and $20 \mathrm{~kg}$ capacity, were used.

The flaming efficiency was calculated by ratio of the number of dried suckers determined 5 days after the flaming to the number of live suckers determined before flaming.

Flaming Efficiency $=($ Dried Sucker per ocak $/$ Live Sucker per ocak) $\times 100$

Table 1. The characteristics of the hazelnut orchard

\begin{tabular}{l|c}
\hline Establishment age of the orchard (year) & 10 \\
\hline Planting form & Brush \\
In and between row spacing $(\mathrm{m} \times \mathrm{m})$ & $6 \times 3$ \\
Number of Ocak $\left(\right.$ ocak da $\left.^{-1}\right)$ & 54 \\
\hline
\end{tabular}
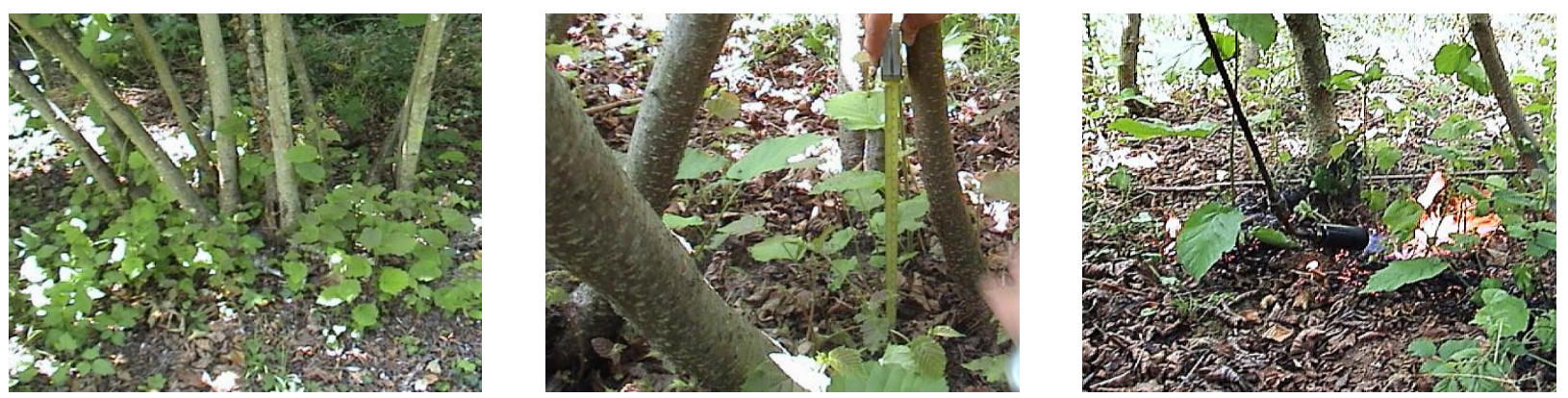

Figure 1. Determination of sucker sizes and flaming process 

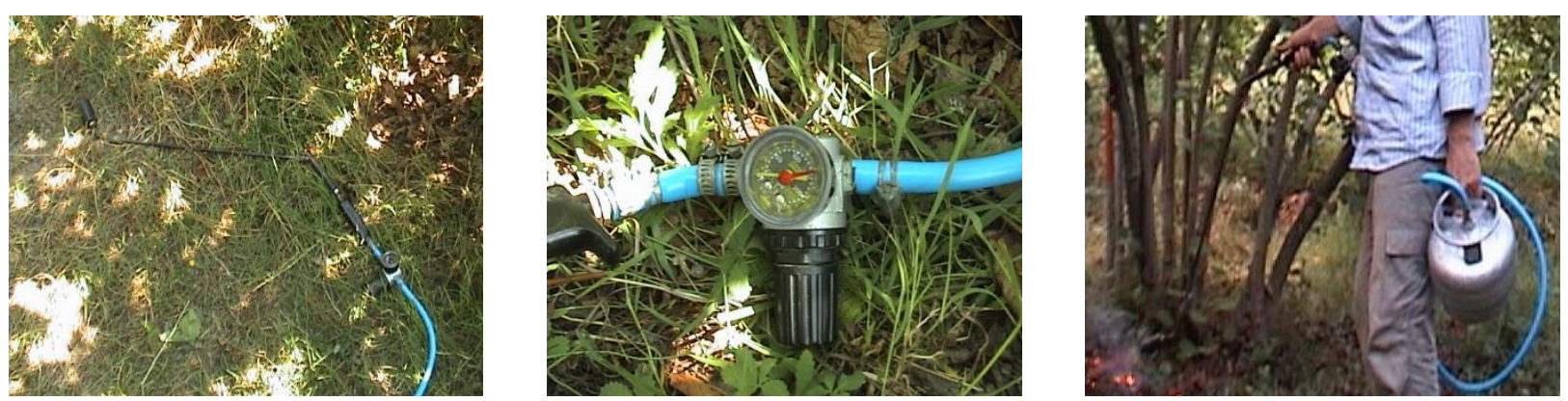

Figure 2. Torch head, pressure meter and LPG tank

Table 2. Some characteristics of basal suckers in ocaks with flaming procedure performed

\begin{tabular}{l|cccc}
\hline & Number of suckers & Number of leaves & Sucker height $(\mathrm{cm})$ & Sucker diameter $(\mathrm{mm})$ \\
\hline 21 June & 25.72 & 4.35 & 18.46 & 2.65 \\
12 July & 56.44 & 5.25 & 18.13 & 2.08 \\
05 August & 60.78 & 5.02 & 22.41 & 2.19 \\
\hline
\end{tabular}

Table 3. Fuel consumption and flaming efficiency values for different pressure and flaming durations

\begin{tabular}{|c|c|c|c|}
\hline LPG pressure & Flaming time $(\mathrm{s})$ & Fuel consumption $\left(\mathrm{kg} \mathrm{da}^{-1}\right)$ & Flaming efficiency $(\%)$ \\
\hline \multirow{6}{*}{$4-3$} & 30 & $9.09^{\mathrm{k}}$ & $14.87^{\mathrm{k}}$ \\
\hline & 60 & $12.02^{\mathrm{j}}$ & $27.10^{\mathrm{j}}$ \\
\hline & 90 & $14.35^{\mathrm{i}}$ & $43.16^{\mathrm{h}}$ \\
\hline & 120 & 17.87 efg & $62.25^{\mathrm{f}}$ \\
\hline & 150 & $18.56^{\text {def }}$ & 79.01 de \\
\hline & 180 & $22.27^{\mathrm{c}}$ & $95.44 \mathrm{ab}$ \\
\hline \multirow{6}{*}{$3-2$} & 30 & $11.29^{\mathrm{j}}$ & $25.96^{\mathrm{j}}$ \\
\hline & 60 & $14.34^{\mathrm{i}}$ & $35.81^{\mathrm{i}}$ \\
\hline & 90 & 16.30 ghi & $56.18^{g}$ \\
\hline & 120 & 19.34 de & $82.48^{\mathrm{d}}$ \\
\hline & 150 & $20.21^{\mathrm{d}}$ & $92.01 \mathrm{bc}$ \\
\hline & 180 & $19.70^{\text {de }}$ & $98.53^{\mathrm{a}}$ \\
\hline \multirow{6}{*}{$2-1$} & 30 & $15.04 \mathrm{hi}$ & $37.00^{\mathrm{i}}$ \\
\hline & 60 & $16.89^{\text {fgh }}$ & $51.22 \mathrm{~g}$ \\
\hline & 90 & 19.07 de & $74.35^{\mathrm{e}}$ \\
\hline & 120 & $23.84^{\mathrm{c}}$ & $88.28^{c}$ \\
\hline & 150 & $27.17^{\mathrm{b}}$ & $100.00^{\mathrm{a}}$ \\
\hline & 180 & $30.83^{\mathrm{a}}$ & $100.00^{\mathrm{a}}$ \\
\hline SEM & & 0.447 & 2.252 \\
\hline Main effect of & & & \\
\hline GP & & $<0.001$ & $<0.001$ \\
\hline FT & & $<0.001$ & $<0.001$ \\
\hline $\mathrm{GP} \times \mathrm{FT}$ & & $<0.001$ & $<0.001$ \\
\hline
\end{tabular}

*Different letters are significantly different at the $5 \%$ level of significance.

Analyses of variance were carried out using the GLM procedure to evaluate the effect of GP, FT and GP $\times$ FT interaction on fuel consumption and flaming efficiency in hazelnut sucker control. Differences between treatments determined by Duncan's multiple range test were deemed significant at $\mathrm{P}<0.05$. Data regarding flaming efficiency were subjected to arcsine $\sqrt{ } \%$ transformation. Ocak means were used as the experimental unit for all analyses. Regression equations and bivariate correlations of traits (FE and GP and FT) were determined by Pearson's correlation using the best linear unbiased estimators of the traits. Regressions were generated based on ocak averages. In the analyses, IBM SPSS statistics software package was used (SPSS v21.0, Armonk, NY: IBM Corp.).

\section{Results and Discussion}

The characteristics of basal suckers in these ocaks are presented in Table 2. It was determined that GP and FT and both together had significant effects $(\mathrm{P}<0.05)$.

The fuel consumption and flaming efficiency for different GP and FT are presented in Table 3. Increasing pressure and duration increased fuel consumption and flaming efficiency. However, with 180 s FT and 3 bar GP, the fuel consumption value was reduced, contrary to the general findings. This reduction can be said to have occurred due to measurement errors linked to the field and plant conditions. It appears more than $90 \%$ flaming efficiency was obtained with 3 bar pressure and $150 \mathrm{~s}$ flaming time (Table 3 ). 
Table 4. Regression model used to estimate flaming efficiency

\begin{tabular}{l|cccc}
\hline \multicolumn{5}{c}{ Model: $\mathrm{a}+\mathrm{b}$ GP $+\mathrm{c}$ FT } \\
\hline & Value & SE & T value & Sig. \\
\hline $\mathrm{a}$ & -21.298 & 2.503 & -8.506 & $<0.0001$ \\
$\mathrm{~b}$ & 10.752 & 0.709 & 15.162 & $<0.0001$ \\
$\mathrm{c}$ & 0.511 & 0.011 & 45.245 & $<0.0001$ \\
\hline \multicolumn{5}{l}{ The coefficient of determination $\left(\mathrm{R}^{2}\right)=0.934$}
\end{tabular}

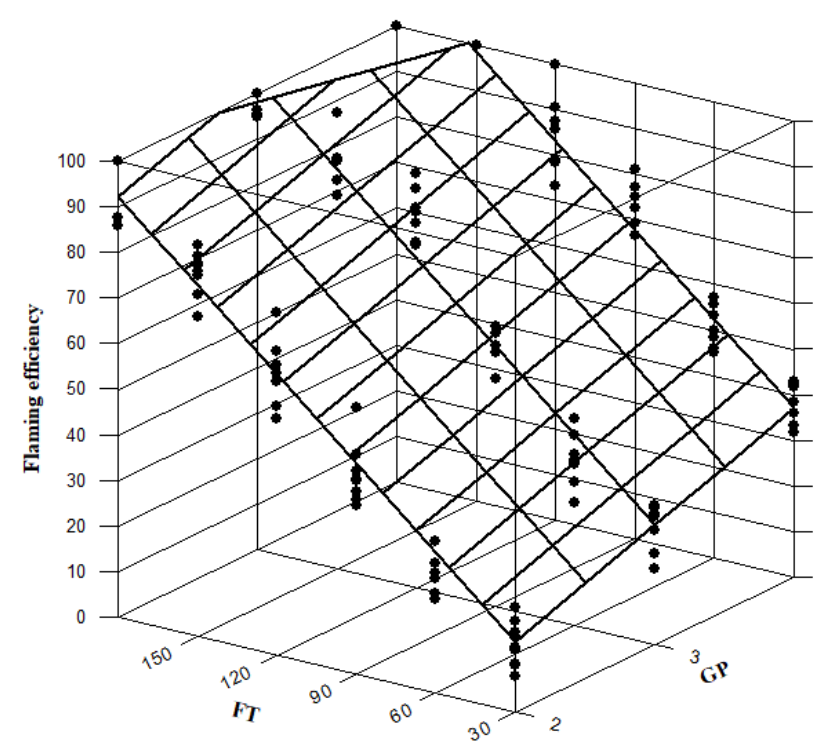

Figure 3. Variation in flaming efficiency of different pressure and flaming durations to flaming hazelnut suckers
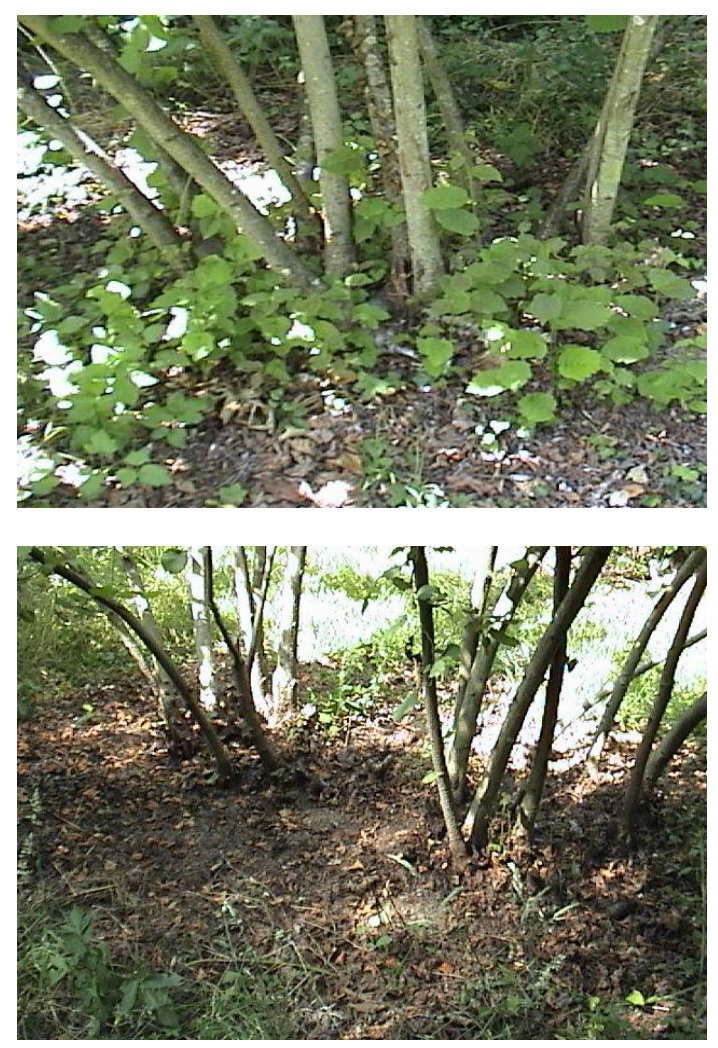

Figure 4. Appearance of hazelnut ocaks before and after the flaming procedure
Among many models used to estimate the flaming efficiency linked to pressure and flaming time, the model with the highest $\mathrm{R}^{2}$ value was chosen and is given in Table 4. This model was found to be statistically significant.

With the regression equation given above, the variation in flaming efficiency to burn hazelnut suckers with different GP and FT is shown in Figure 3. Flaming efficiency displayed variations within large margins (9\% to $100 \%$ ). As GP and FT increased, flaming efficiency also increased.

In Italy, two different types of torch were used for sucker cleaning in single-stem hazelnut orchards and flaming efficiency was classified as good if above $90 \%$, moderate from 70-90\% and low efficiency for less than $70 \%$. With the handheld torch at 1 bar GP, each sucker was flamed for 30 and $60 \mathrm{~s}$ and $30 \mathrm{~s}$ FT was reported to have better flaming efficiency, while 60 s completely burned the suckers. They stated the need to increase flame intensity with FT and GP when many suckers are present (Tomasone et al., 2010).

\section{Conclusion}

The research findings showed that the torch flaming method is a useable alternative method for hazelnut sucker cleaning (Figure 4). GP and FT had significant effects on fuel consumption and flaming efficiency. According to the obtained results, $150 \mathrm{~s}$ FT and 3 bar GP is sufficient for the flaming application. Durations above this time will increase fuel consumption and time loss.

During the application, as the main stems were not directly exposed to heat, no damage was observed to the main stems in the clusters.

No changes were made to the torch used in the trials that would increase the cost. The low cost of the torch will allow manufacturers to use it easily.

Sucker cleaning with flames is an intervention method that can be fully mechanized. Especially in flat and wide hazelnut orchards, torch machines mounted on tractors may be manufactured and brought into practice. In this way, labor efficiency and more ergonomic working conditions may be provided.

The negative ergonomic working conditions of sucker cleaning with traditional methods (hoe, hazelnut knife, etc.) will be removed with the flaming method.

Additionally, chemical herbicides used for plant cultivation for nearly 50 years have been shown to be one of the causes of some diseases and disorders occurring in society. As a result, the whole world has entered a search for methods other than chemical herbicides which negatively affect the health of humans and the environment. Chemical herbicide use causes pollution of both groundwater and surface waters and creation of herbicide residues in foods. In recent times, the sensitivity of society to the environment has rapidly increased and the use of chemicals has threatened human health causing an increase in the interest in flaming methods and machines as a non-chemical method.

For sustainable agriculture to be realized, it is necessary to develop alternative systems and machines, apart from the use of chemicals, to preserve our soil and water resources and to leave a more habitable world for future generations. 


\section{References}

Ascard J. 1995. Effects of flame weeding on weed species at different developmental stages. Weed Research, 35(5):397411. https://doi.org/10.1111/j.1365-3180.1995.tb01636.x

Ascard J. 1997. Flame weeding: effects of fuel pressure and tandem burners. Weed Research, 37:77-86. https://doi.org/10.1046/j.1365-3180.1996.d01-5.x

Beyhan MA, Pinar Y. 1996. An investigation of using a mechanical scrub-cleaning tool at desuckering of hazelnut (in Turkish). Proceedings of the Agricultural Education $150^{\text {th }}$ Anniversary, Hazelnut and Other Nuts Symposium, 10-11 January, Ondokuz Mayıs University Agriculture Faculty, Samsun, Turkey, p 119-133.

Beyhan N. 2007. Effects of planting density on yield and quality characteristics of hazelnut (cv. Palaz) in a hedgerow training system. Canadian Journal Plant Science, 87:595-597. https://doi.org/10.4141/P05-064

Brunclik P, Lacko-Bartosova M. 2001. Evaluation of weed species susceptibility to flaming. Proceedings of the International Scientific Conference on the Occasion of the $55^{\text {th }}$ Anniversary of the Slovak Agricultural University in Nitra, Acta Fytotechnica et Zootechnica, 4(5):83-84.

Chehade LA, Fontanelli M, Martelloni L, Frasconi C, Raffaelli M, Peruzzi A. 2018. Effects of flame weeding on organic garlic production. HortTechnology, 28(4):502-508. https://doi.org/10.21273/HORTTECH04081-18

Dolci M, Radicati di Brozolo 1, Schellino 1. 2005. Further experiments on control of sucker growth in hazelnuts (Corylus avellana L,) with new esters of 1-naphthylacetic acid. Acta Horticulturae, 686:271-276 https://doi.org/10.17660/ActaHortic.2005.686.37

Horesh A, Goldwasser Y, Igbariya K, Peleg Z, Lati RN. 2019. Propane flaming as a new approach to control mediterranean. Invasive Weeds Agronomy, 9:187-198. https://doi.org/10.3390/agronomy9040187

İslam, A. 2018. Hazelnut culture in Turkey. Akademik Ziraat Dergisi, 7(2):259-266. http://doi.org/10.29278/azd.476665

Knezevic SZ. 2017. Flame weeding in corn, Soybean and Sunflowers. Proceedings $8^{\text {th }}$ International Conference on Information and Communication Technologies in Agricultura, Food and Environment, (HAICTA 2017), Chania, Greece, 21-24 September, p 390-394.

Kılıç O, Ceyhan V, Alkan I. 2009. Determinants of economic efficiency: A case study of hazelnut (Corylus avellana L) farms in Samsun Province, Turkey. New Zealand Journal of Crop and Horticultural Science, 37(3):263-270. https://doi.org/10.1080/01140670909510272
Nemming A. 1993. Costs of flame cultivation. In Symposium on Engineering as a Tool to Reduce Pesticide Consumption and Operator Hazards in Horticulture, 372:205-212. https://doi.org/10.17660/ActaHortic.1994.372.24

Rifai MN, Lacko-Bartosova M, Brunclik P. 2000. Alternative methods of weed control in apple orchard. Pakistan Journal of Biological Science, 3(6):933-938. https://doi.org/10.3923/pjbs.2000.933.938

Serdar Ü, Akyüz B. 2018. Sucker management methods in hazelnut cultivation. Acta Horticulturae, 1226:309-314. https://doi.org/10.17660/ActaHortic.2018.1226.46

Smith DC, Erdoğan V. 2001. Elimination of hazelnut sucker by disbudding. Acta Horticulturae, 556:263-268. https://doi.org/10.17660/ActaHortic.2001.556.38

Sivesind EC, Leblanc ML, Cloutier DC, Seguin P, Stewart KA. 2009. Weed response to flame weeding at different developmental stages. Weed Technology, 23(3):438-443. https://doi.org/10.1614/WT-08-155.1

Tomasone R, Colorio G, Cedrola C, Pagano M (2009). Mechanical and physical control of hazelnut suckers. Proc. VII International Congress on Hazelnut, p 407-412. https://doi.org/10.17660/ActaHortic.2009.845.63

Tomasone R, Colorio G, Cedrola C, Pagano M. 2010. Thermal control of hazelnut suckers. XVII ${ }^{\text {th }}$ World Congress of the International Commission of Agricultural Engineering (CIGR), Québec City, Canada, p 13-17.

Tous J, Girona J, Tasias J. 1994. Cultural practices and costs in hazelnut production. Acta Horticulturae, 351:395-418. https://doi.org/10.17660/ActaHortic.1994.351.44.

Ulloa SM, Datta A, Knezevic SZ. 2010. Tolerance of selected weed species to broadcast flaming at different growth stages. Crop Protection, 29:1381-1388. https://doi.org/10.1016/j.cropro.2010.07.017

Yildız T, Tekgüler A. 2014. The effects of different maturity times of fruit ripening and limb connection heights on the percentages of fruit removal in mechanical harvesting of hazelnut (Cv. Yomra). Journal of Agricultural Sciences, 20:38-47. https://doi.org/10.1501/Tarimbil_0000001263

Y1ldiz T. 2016. Labor requirements and work efficiencies of hazelnut harvesting using traditional and mechanical pick-up methods. Turkish Journal of Agriculture and Forestry, 40:301-310. https://doi.org/10.3906/tar-1508-114

Y1lmaz F. 2017. The Effects of Sucker Control and Fertilizing on Yield, Quality and Nutrient Content in Hazelnut (in Turkish). MSc Thesis, Graduate School of Natural an Applied Science, Ondokuz Mayis University, Samsun Turkey. 